\title{
Cancer vaccines: a newer front of immunotherapy
}

\author{
Sonia Puri, Naveen Krishan Goel, Veenal Chadha*, Praizy Bhandari
}

Department of Community Medicine, GMCH 32, Chandigarh, Punjab, India

Received: 10 October 2018

Accepted: 11 November 2018

\section{*Correspondence:}

Dr. Veenal Chadha,

E-mail: veenalchadha88@gmail.com

Copyright: () the author(s), publisher and licensee Medip Academy. This is an open-access article distributed under the terms of the Creative Commons Attribution Non-Commercial License, which permits unrestricted non-commercial use, distribution, and reproduction in any medium, provided the original work is properly cited.

\begin{abstract}
Vaccines have been used as a promising instrument over the years to combat the dreadful communicable diseases. But now owing to epidemiological transition as the burden of non-communicable diseases has increased, efforts are now being made globally to use this weapon for non-communicable diseases like cancer. Cancer vaccines belong to a class of substances known as "biological response modifiers". These work by stimulating or restoring the immune system's ability to fight infections and disease. There are two broad types of cancer vaccines: Preventive (or prophylactic) vaccines and Treatment or therapeutic vaccines. Cancer treatment vaccines are made up of cancer cells, parts of cells or pure antigens. Sometimes a patient's own immune cells are removed and exposed to these substances in the lab to create the vaccine. Cancer treatment vaccines differ from the vaccines that work against viruses. These vaccines try to get the immune system to mount an attack against cancer cells in the body. Instead of preventing disease, they are meant to get the immune system to attack a disease that already exists. Preventive vaccines are intended to prevent cancer from developing in healthy people. And in fact, many evidence-based studies have proven the decrease in morbidity and mortality in various cancers by usage of some of the vaccines like cervical cancer vaccine etc. The biggest challenges currently facing preventive anti-cancer vaccines are clinical, social, and economic in nature. This article is an effort to highlight the advances in various cancer vaccines, so done, to use them on preventive and therapeutic front.
\end{abstract}

Keywords: Immunotherapy, Preventive, Vaccines, Therapeutic

\section{INTRODUCTION}

Vaccines, most successful weapon against dreadful diseases some of which were greatest scourges of humankind have drastically decreased mortality over the time. Vaccine research has now opened up a second front by applying vaccination as a therapy for people already suffering from disease, which is not susceptible to a preventive approach. That is, yielding of an efficient tool against cancer.

More recently, the concept of vaccination has been developed into a potentially novel strategy to treat and prevent cancer formation, progression and spread. ${ }^{1}$ Approximately 100 years ago, researchers attempted to stimulate a tumor specific, therapeutic immune response to tumors by injecting patients with cells and extracts from their own tumors or tumors of the same type from different individuals. ${ }^{2}$

During the last decade, great efforts have been made to develop immunotherapeutic approaches for the treatment of malignant diseases as alternatives to traditional chemo and radiotherapy. A quintessential goal of immunotherapy in cancer is treatment with vaccines that elicit potent antitumor immune responses without side effects. $^{3}$

\section{What are cancer vaccines?}

Cancer vaccines belong to a class of substances known as "biological response modifiers". These work by 
stimulating or restoring the immune system's ability to fight infections and disease. ${ }^{4}$ Cancer treatment vaccines are made up of cancer cells, parts of cells or pure antigens. Sometimes a patient's own immune cells are removed and exposed to these substances in the lab to create the vaccine.

Once the vaccine is ready, it's injected into the body to increase the immune response against cancer cells. Cancer treatment vaccines differ from the vaccines that work against viruses. These vaccines try to get the immune system to mount an attack against cancer cells in the body. Instead of preventing disease, they are meant to get the immune system to attack a disease that already exists. Vaccines are often combined with other substances or cells called adjuvants that help boost the immune response even further.

There are two broad types of cancer vaccines: Preventive (or prophylactic) vaccines and Treatment or therapeutic vaccines. ${ }^{5}$ Preventive vaccines are intended to prevent cancer from developing in healthy people. Currently, all of the licensed preventive anti-cancer vaccines used in clinical practice target virus-causing cancers (oncoviruses).

The most common one is the HPV vaccine (Gardasil) that was first licensed by the FDA in 2006 and recommended for use in females between the ages of 9 and 26 for the prevention of cervical cancer along with various other HPV-associated cancers (e.g., vaginal cancers, vulvar cancers, anal cancers, HPV-induced oral cancers, etc. Gardasil targets four specific subtypes of the HPV -6 , 11,16 and 18 - of which HPV 16 and 18 cause about 70 percent of all cases of cervical cancer worldwide.

Treatment (or therapeutic) vaccines, are intended to treat an existing cancer by strengthening the body's natural immune response against the cancer. It is used to treat cancer after it has already appeared. There are two main types of such therapeutic vaccines: autologous vaccines and allogenic vaccines. ${ }^{6,7}$

Treatment vaccines are a form of immunotherapy. Rapid advancements in the understanding of the immune system and its role in cancer have allowed for the development of therapeutic vaccines that utilize the host's own immune system to essentially prime it to specifically target, attack, and kill tumor cells. To date, the only therapeutic anti-cancer vaccine that has been licensed for use in clinical practice is sipuleucel-T (Provenge), which is used for the treatment of prostate cancer. ${ }^{8}$ It was first licensed by the U.S. Food and Drug Administration (FDA) in 2010 for use in the treatment of asymptomatic/minimally symptomatic metastatic castration-resistant prostate cancer (mCRPC). Unlike the HPV vaccine that relies primarily on generating an antibody response to prevent initial HPV infection,
sipuleucel-T (vaccine for prostate metastatic cancer) intends to treat the cancer.

\section{The origin of concept of cancer vaccines}

In 1891, Dr. William Coley, the "Father of Immunotherapy," made the first attempt to stimulate the immune system for improving a cancer patient's condition by intratumoral injections of inactivated Streptococcus pyogenes and Serratia marcescens. ${ }^{9}$ The idea came from the observation of spontaneous remissions of sarcomas in rare-cancer patients who had developed erysipelas.

Despite his reported effective responses in patients, his work was viewed with skepticism by the scientific community. Today, the field of immunology has developed into a highly sophisticated specialty, and the modern science of immunology has shown that Coley's principles were correct. Indeed, the bacillus calmetteguerin (BCG) that is one similar example as the Coley's Toxin, is still being used intravesically to treat superficial bladder cancer.

\section{CURRENT SCENARIO}

Viruses are the underlying cause in approximately 10 percent of all cases of cancer and are therefore an attractive therapeutic target for cancer prevention. Previous success with vaccines used to treat and prevent infectious diseases caused by viruses have provided a platform for identifying oncoviruses and utilizing the host immune system to effectively target and eliminate them. The biggest challenges currently facing preventive anticancer vaccines are clinical, social, and economic in nature. Debates are currently ongoing, and key decisions are still yet to be made with regard to how preventive anti-cancer vaccines can be delivered to a general population in an ethical and cost-effective manner. ${ }^{10}$ Over the past few years, a handful of anti-cancer vaccines have been licensed and approved for use in clinical practice, thus providing a breakthrough in the field. However, the path has not always been easy, with many hurdles that have had to be overcome in order to reach this point.

Nevertheless, with more anti-cancer vaccines currently in development, there is still hope that they can eventually become routine tools used in the treatment and prevention of cancer in the future. Of the handful of anti-cancer vaccines currently being used in clinical practice, perhaps the most famous of these is a prophylactic vaccine that targets a subset of the human papilloma virus ( $\mathrm{HPV} \dagger$ ), which causes cervical cancer. For its discovery and development, Harald zur Hausen was awarded the 2008 Nobel Prize in Physiology and Medicine, 11 serving as a breakthrough moment and underlining the credibility of vaccination as a means of treating and preventing cancer. ${ }^{11}$ 
Table 1: Currently used anticancer vaccines.

\begin{tabular}{|c|c|c|}
\hline Anti-cancer vaccines & Effective against Cancers & Target group \\
\hline $\begin{array}{l}\text { Hepatitis vaccine } \\
\text { (Engerix-B, Enivac B) }\end{array}$ & Hepatocellular cancer & $\begin{array}{l}\text { Potent for all age groups, especially } \\
\text { given to new-borns, after accidental } \\
\text { exposure and chronic hepatic } \\
\text { infections. }\end{array}$ \\
\hline \multirow{8}{*}{$\begin{array}{l}\text { Human Papillomavirus (HPV) } \\
\text { RQuadrivalent recombinant } \\
\text { vaccine, (Types 6, 11, 16, 18) } \\
\text { (Gardasil) }\end{array}$} & Cervical cancer & \multirow{8}{*}{$\begin{array}{l}\text { Females } 9 \text { to } 26 \text { years of age for } \\
\text { Prevention against cervical cancer } \\
\text { caused by (HPV) Types } 6,11,16 \text {, and } \\
18 \text {. } \\
\text { Vaccination in boys and men } 9 \text { to } \\
26 y e a r s \text { of age for the prevention of } \\
\text { genital warts caused by HPV types } 6 \\
\text { and } 11 \text { which do not cause } \\
\text { malignancy. }\end{array}$} \\
\hline & Genital warts (condyloma acuminata) & \\
\hline & Cervical adenocarcinoma in situ (AIS) & \\
\hline & Cervical intraepithelial neoplasia & \\
\hline & $(\mathrm{CIN})$ grade 2 and grade 3 & \\
\hline & $\begin{array}{l}\text { Vulvar intraepithelial neoplasia (VIN) } \\
\text { grade } 2 \text { and grade } 3\end{array}$ & \\
\hline & $\begin{array}{l}\text { Vaginal intraepithelial neoplasia (vain) } \\
\text { grade } 2 \text { and grade } 3\end{array}$ & \\
\hline & $\begin{array}{l}\text { Cervical intraepithelial neoplasia } \\
\text { (CIN) grade } 1\end{array}$ & \\
\hline \multirow{5}{*}{$\begin{array}{l}\text { Human Papillomavirus Bivalent } \\
\text { Recombinant vaccine (Types } 16 \text { and } \\
\text { 18) (Cervarix) }\end{array}$} & Cervical cancer & \multirow{5}{*}{$\begin{array}{l}\text { Prevention of cervical cancer, in } \\
\text { Females } 10 \text { to } 25 \text { years of age for } \\
\text { prevention of cervical cancer } \\
\text { especially caused by HPV type } 16 \\
\text { and } 18 .\end{array}$} \\
\hline & Cervical intraepithelial neoplasia & \\
\hline & $(\mathrm{CIN})$ grade 2 or worse & \\
\hline & Adenocarcinoma in situ, & \\
\hline & $\begin{array}{l}\text { Cervical intraepithelial neoplasia } \\
\text { (CIN) grade } 1\end{array}$ & \\
\hline $\begin{array}{l}\text { Sipuleucel-T (Provenge) (Approved } \\
\text { in US) }\end{array}$ & Prostate cancer & $\begin{array}{l}\text { For males with metastatic, } \\
\text { symptomatic, minimally } \\
\text { symptomatic, castrate-resistant } \\
\text { (hormone refractory) prostate cancer. }\end{array}$ \\
\hline
\end{tabular}

\section{HPV VACCINE}

Persistent infections with high-risk HPV types can cause cervical cancer, anal cancer, oropharyngeal cancer, and vaginal, vulvar, and penile cancers. Three vaccines are approved by the US Food and Drug Administration (FDA) to prevent HPV infection. Hepatitis B virus (HBV) vaccines. Chronic HBV infection can lead to liver cancer. The FDA has approved multiple vaccines that protect against HBV infection. Two vaccines, Engerix-B and Recombivax $\mathrm{HB}$, protectagainst HBV infection only. Both vaccines are approved for use in individuals of all ages. In April 2010, the FDA approved the first cancer treatment vaccine. This vaccine, sipuleucel-T (Provenge $\AA$ ), is approved for use in some men with metastatic prostate cancer. ${ }^{12}$ Unlike some other cancer treatment vaccines, sipuleucel-T is customized to each patient. The vaccine is created by isolating immune system cells called dendritic cells, which are a type of antigen-presenting cell (APC), from a patient's blood through a procedure called leukapheresis (Table 1). Effective, safe and enduring cancer treatments constitute major challenges of medical sciences, with therapeutic cancer vaccines emerging as attractive approaches for provoking long-lasting protective antitumor immunity. Recent approval of the first therapeutic cancer vaccine will pave the way for developing innovative, next generation of vaccines with enhanced antitumor potency. Based on current data from clinical trials and the safety profiles of therapeutic vaccines, they will most probably be used in the adjuvant or neoadjuvant setting for the treatment of patients with minimal residual disease or more indolent metastatic disease, or those patients with a high risk of recurrence.

A better understanding of host-tumor interactions and tumor immune escape mechanisms are required to develop effective cancer vaccines. Identification of unique tumor gene or protein products responsible for transformation of normal cells into tumor cells and promoting cancer progression will also uncover new potential targets for vaccine therapy. In addition, immune signatures will have to be established and exploited to define patient populations who will most likely respond to and benefit from vaccine therapies. ${ }^{13}$ Strategically combining vaccine strategies with other agents or approaches that synergistically enhance antitumor immunity and/or engage complementary antitumor responses should also lead to further improved clinical outcomes.

\section{Promising anti-cancer vaccines currently in development}

Vaccines are not yet a major type of treatment for cancer. Researchers have been trying to develop vaccines to fight cancer for decades, but this has proven to be harder than was first thought. As researchers have learned over the 
years, the immune system is very complex. It has also become clear that cancer cells have different ways of eluding the immune system, which makes creating effective vaccines difficult. ${ }^{14}$ Researchers are using the knowledge gained in recent years to improve how they develop cancer vaccines.

They are studying the best way to give vaccines, looking to see if they work better when used alone or with other types of cancer treatments. For example, vaccines are now often given along with other substances (called adjuvants) that help boost the body's immune response, which might help the vaccines work better. ${ }^{15}$ (Table 2) Much recent attention has been given to the use of ex vivo-modified dendritic cells in tumor vaccine therapy; that is, dendritic cells 16 modified in the laboratory.
While there are only a handful of anti-cancer vaccines currently available in clinical practice, over the years there have been many more that have been put through clinical trials.

One of the most advanced anti-cancer vaccines currently in development is the gp100 melanoma vaccine. Currently, two large ongoing phase III clinical trials (START and INSPIRE) are testing L-PLP 25 for the treatment of non-small cell lung cancer. ${ }^{17}$ One of the few types of anti-cancer vaccines currently in development for targeting TSAs is the antiidiotype vaccine. Cancer vaccines are now entering into a renaissance era, thanks to the series of clinical trials that are hopeful of yielding encouraging clinical outcomes for a plethora of cancers.

Table 2: Future cancer vaccines in development.

\begin{tabular}{|c|c|}
\hline Cancer & Developmental research status of cancer vaccine ${ }^{18,19}$ \\
\hline Bladder cancer & $\begin{array}{l}\text { One study is testing the effectiveness of a vaccine made from a virus, researchers modified to } \\
\text { contain HER } 2 \text { cells, which live on the surface of some bladder cancer tumors. }\end{array}$ \\
\hline Brain tumors & $\begin{array}{l}\text { Researchers are targeting at certain molecules on the surface of brain tumor cells for } \\
\text { development of vaccine. Some focus on newly diagnosed brain cancer and on recurred one. }\end{array}$ \\
\hline Breast cancer & $\begin{array}{l}\text { Several studies are testing treatment vaccines for breast cancer, given alone or with other } \\
\text { therapies. Other researchers are working to get prevention vaccines into clinical trials. }\end{array}$ \\
\hline Cervical cancer & $\begin{array}{l}\text { The FDA already approved cervical cancer prevention vaccines. } \\
\text { Now work continues on treatment vaccines that help to treat the disease in its various stages. }\end{array}$ \\
\hline Colorectal cancer & $\begin{array}{l}\text { Researchers are creating treatment vaccines that encourage the body to attack cells with } \\
\text { antigens thought to cause colorectal cancer. These antigens include carcinoembryonic antigen } \\
\text { (CEA), MUC1, guanylyl cyclase C, and NYESO1. }\end{array}$ \\
\hline Kidney cancer & $\begin{array}{l}\text { Vaccines are being developed to treat kidney cancer at various stages and to avoid } \\
\text { recurrence.Efforts are going to either make patient customized vaccine or from tumour } \\
\text { surface proteins or blood vessel cells in the tumor }\end{array}$ \\
\hline Leukemia & $\begin{array}{l}\text { Treatment vaccines for various types of leukemia, such as acute myeloid leukemia and } \\
\text { chronic lymphocytic leukemia are basically being focused on. Also, vaccines benefitting the } \\
\text { other treatment modalities such as stem cell transplants are aimed at. }\end{array}$ \\
\hline Lung cancer & $\begin{array}{l}\text { Treatment vaccines in clinical trials target antigens- MAGE3, which is found in } 42 \% \text { of lung } \\
\text { cancers and NYESO1, found in } 30 \% \text { of lung cancers. Others target antigens such as p53, } \\
\text { survivin, and MUC1. }\end{array}$ \\
\hline Melanoma & $\begin{array}{l}\text { Researchers are testing several vaccines, given alone or with other therapies using destroyed } \\
\text { melanoma cells. }\end{array}$ \\
\hline Myeloma & $\begin{array}{l}\text { Several clinical trials are in process studying vaccines with multiple myeloma near remission, } \\
\text { smoldering myeloma or with autologous stem cell transplant. }\end{array}$ \\
\hline Pancreatic cancer & $\begin{array}{l}\text { Researchers are working on several treatment vaccines designed to boost the immune } \\
\text { system's response to pancreatic cancer cells either alone or in combination with other } \\
\text { therapy. }\end{array}$ \\
\hline Prostate cancer & $\begin{array}{l}\text { sipuleucel } \mathrm{T} \text { is a vaccine to treat men with metastatic prostate cancer. Now researchers are } \\
\text { trying to find if vaccine can help men with less advanced prostate cancer. }\end{array}$ \\
\hline
\end{tabular}

\section{CONCLUSION}

Cancer vaccines are not just a dream for the future, overall, the state of anti-cancer vaccines looks promising. With a few anti-cancer vaccines currently in clinical practice and several more currently in phase III clinical trials, the future certainly looks bright for the once muchmaligned concept. The question however still remains: Has a revolution truly begun or are anti-cancer vaccines just a one-hit wonder?

\section{Funding: No funding sources}


Conflict of interest: None declared

Ethical approval: Not required

\section{REFERENCES}

1. Human Papillomavirus (HPV) Vaccines Available at https://www.cancer.gov/about-cancer/causesprevention/vaccines-fact-sheet

2. Chen DS, Mellman I. Oncology meets immunology: the cancer-immunity cycle. Immun. 2013;39(1):1-10.

3. Henrique Neves, Hang Fai Kwok. Recent advances in the field of anti-cancer immunotherapy. BBA Clinic. 2015;3:280-8.

4. Butterfield LH. Cancer vaccines. BMJ. 2015;22:350

5. Itoh K, Yamada A, Mine T, Noguchi M. Recent advances in cancer vaccines: an overview. Jap J Clinic Oncol. 2008;39(2):73-80.

6. What's new in cancer immunotherapy research? Available https://www.cancer.org/treatment/treatments-andside-effects/treatment-types/immunotherapy/whatsnew-in-immunotherapy-research.html

7. Aurisicchio L, Ciliberto G. Genetic cancer vaccines: current status and perspectives. Expert opinion on biological therapy.2012;12(8):1043-58.

8. Antonarakis ES, Drake CG. Current status of immunological therapies for prostate cancer. Curr Opin Urol. 2010;20(3):241-46.

9. Guo C, Manjili MH, Subjeck JR, Sarkar D, Fisher PB, Wang XY. Therapeutic Cancer Vaccines: Past, Present and Future Adv Cancer Res. 2013;119:42175 .

10. Wong KK, Li WA, Mooney DJ, Dranoff G. Advances in Therapeutic Cancer Vaccines. Adv Immunol. 2016;130:191-249.

11. Adams A, Wise-Draper T, Wells S. Human Papillomavirus Induced Transformation in Cervical and Head and Neck Cancers. Cancers. 2014;6(3):1793-820.
12. Kantoff PW, Higano CS, Shore ND, Berger ER, Small EJ, Penson DF, et al; IMPACT Study Investigators. Sipuleucel-T immunotherapy for castration-resistant prostate cancer. N Engl J Med 2010;363(5):411-22.

13. Vonderheide RH, Nathanson KL. Immunotherapy at large: the road to personalized cancer vaccines. Nat Med. 2013;19(9):1098-100.

14. Selvarajan S, George M, Kumar S, Dkhar SA. Recent Advances in Cancer Vaccines - An Update. J Cancer Res Update 2012;1(2):173-80

15. Slingluff CL Jr. The present and future of peptide vaccines for cancer: single or multiple, long or short, alone or in combination? Cancer J 2011;17(35):34350.

16. Palucka K, Ueno H, Fay J, Banchereau J. Dendritic cells and immunity against cancer. J Intern Med 2011;269(1):64-73

17. Ma K, Tang YH. Therapeutic vaccines explored in patients with non-small cell lung cancer. Anticancer Agents Med Chem. 2014;14(2):256-64.

18. Slingluff CL, Lee S, Zhao F, Chianese-Bullock KA, Olson WC, Butterfield LH, et al. A randomized phase II trial of multiepitope vaccination with melanoma peptides for cytotoxic $\mathrm{T}$ cells and helper $\mathrm{T}$ cells for patients with metastatic melanoma (E1602). Clin Cancer Res 2013;19:4228-38

19. Aranda F, Vacchelli E, Eggermont A, Galon J, Sautès-Fridman C, Tartour E, et al. Trial watch: peptide vaccines in cancer therapy. Oncoimmunol 2013;2(12):e26621.

Cite this article as: Puri S, Goel NK, Chadha V, Bhandari P. Cancer vaccines: a newer front of immunotherapy. Int J Reprod Contracept Obstet Gynecol 2018;7:5214-8. 